\title{
Harmony as an Ethical and Political Idea
}

\author{
Andrej ULE*
}

\begin{abstract}
Although the idea of harmony is one of the basic Confucian ideas, two of its key classic authors, Mengzi and Xunzi, emphasised either the ethical-personal or socio-political aspects, respectively, and this contrast was only maintained and deepened in later Chinese history. The socio-political considerations of harmony often considers an ideal state of community to be static, with social and ethical states being preserved, rather than dynamic. On the other hand, personal and spiritual harmony was valued by artists and autonomous thinkers, which often found themselves in conflict with the state. However, an open conflict between these two lines of thought very seldom if at all appeared in traditional China, and thus the differences often remained implicit. A self-cultivated individual without external social support was condemned to social isolation and personal defeat. Even among contemporary Chinese Marxist politicians and theorists, the idea of a "harmonious society" follows Xunzi's rather legalist emphasis, even if (in Marx view) the term "social harmony" stands for some surface phenomena of seemingly harmonious societal interrelationship, covering up the brutal reality of social and economic contradictions. I argue that not only in China, but also elsewhere, a better balance is needed between the personal and the social ideas of harmony. However, manifesting harmony can become something worthwhile only if it becomes a part of a broader project, namely that of active solidarity based on the reciprocal and universal cultivation of personal dignity and virtuous humaneness.
\end{abstract}

Key words: harmony, Confucianism, harmonious society, Marxism, solidarity

\section{Harmonija kot etična in politična ideja}

\section{Izvleček}

Čeprav je ideja harmonije ena osrednjih konfucijanskih idej, sta dva od njenih osrednjih klasičnih avtorjev, Mengzi in Xunzi, poudarjala bodisi etično-osebne ali družbenopolitične vidike in to nasprotje se je ohranjalo in poglabljalo v nadaljnji zgodovini Kitajske. Družbeno-politično pojmovanje harmonije se pogosto opira na misel o idealnem stanju družbe, kjer se družbeno in etično stanje ohranja kot nekaj statičnega, ne pa dinamičnega. Po drugi strani so umetniki in samostojni misleci cenili osebno in duhovno harmonijo in so se zato pogosto znašli v konfliktu z državo. Vendar je v tradicionalni Kitajski le redko,

Andrej Ule, PhD, Full professor (emeritus), Department of Philosophy,

Faculty of Arts, University of Ljubljana.

Email address: andrej.ule[at]guest.arnes.si

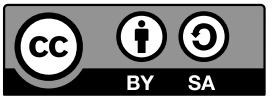


če sploh, prihajalo do odkritega konflikta med tema pojmovanjema harmonije, zaradi česar so razlike pogosto ostajale implicitne. Samo-kultiviran posameznik brez zunanje socialne podpore je bil obsojen na družbeno izolacijo in osebni poraz. Celo med sodobnimi kitajskimi marksističnimi politiki in teoretiki zamisel o »harmonični družbi« sledi Xunzijevim precej legalističnim poudarkom, čeprav (po Marxovem pojmovanju) pojem »družbene harmonije« zajema površinske pojave domnevno harmoničnih družbenih odnosov, ki prikrivajo surovo naravo družbenih in ekonomskih protislovij. Zagovarjam misel, da ne le v Kitajski, temveč tudi drugje po svetu, potrebujemo boljše ravnotežje med osebnimi in družbenimi predstavami o harmoniji. Vendar je dejanska harmonija lahko nekaj vredna le, če postane del širšega projekta, namreč projekta aktivne solidarnosti, ki sloni na medsebojni in splošni kultivaciji osebnega dostojanstva in vrline človečnosti.

Ključne besede: harmonija, konfucianstvo, harmonična družba, marksizem, solidarnost

\section{Introduction}

The idea of "harmony" (he 和) is one of the central ethical, social, and political ideas of Chinese culture (Zhihe 2012). It is the central idea of Confucianism, but it was also present in Daoism, Legalism and Chinese Buddhism. It encompasses the fundamental principles of nature, society and humanity. It is also a prerequisite for cultivating one's morality, protecting one's family, governing one's nation and stabilising the world.

In The Doctrine of the Mean (Zhongyong 中庸), one of the Confucian classics, ascribed to Zisi, the grandson of Confucius, one reads the deep connection of harmony with the Dao of the world:

喜、怒、哀、樂之未發、謂之中。發而皆中節、謂之和。中也 者、天下之大本也。和也者、天下之達道也。致中和、天地位 焉、萬物育焉

Pleasure and anger, sorrow and joy: before they emerge they are called centred; emerging by the proper rhythms they are called harmonious. Centred: this is the great root of the world. Harmonious: this is the ultimate Dao of the world. Reaching centred harmony, heaven and earth take their proper places and the things of the world are nurtured thereby. (Eno 2016a, 1)

Harmony presents the dynamic synthesis of unity and difference. The concept of harmony corresponds well with the fundamental Chinese mode of looking for social and political harmony, i.e., to correlative thinking which follows the ever fluid unity of contrarieties (tongbian 通變). Yijing (易經), The Book of Changes, a classic text in Chinese culture, emphasises "Grand Harmony" (datong 大同), 
which claims that the world is full of different things, yet all these harmonise even as they constantly change. As such harmony can be said to stand at the very core of Chinese traditional culture, and the yin-yang (陰陽) form is one of its main symbols.

According to Confucius, striving for harmony was mostly an ethical principle. Striving after harmony is what characterises the behaviour of a "virtuous man" (junzi 雲子). Confucius in The Analects (論語) connected the striving for harmony with the fidelity to rites and rituals of propriety that were respected in the Zhou dynasty ( $l i$ 礼)

有子曰:「禮之用, 和為貴。先王之道斯為美, 小大由之。有所不 行，知和而不以禮節之，亦不可行也。

Master You said: In the practice of $l i$, harmony is the key. In the dao of the kings of old, this was the beauty. In all affairs, great and small, follow this. Yet there is one respect in which one does not. To act in harmony simply because one understands what is harmonious, but not to regulate one's conduct according to $l i$ : indeed, one cannot act in that way. (Eno 2015,1, 12)

One of the main functions of rites and rituals of propriety $(l i)$ is precisely to harmonise people of various kinds. Confucius and his disciples take rituals as a central aspect of government and believe that, through the good use of rituals, good government can create a harmonious society.

Confucius advocates the harmonious coexistence of different individuals, but without seeking likeness with others:

\section{子曰:「君子和而不同，小人同而不和。」}

The Master said: The junzi acts in harmony with others but does not seek to be like them; the small man seeks to be like others and does not act in harmony. (Lunyu 2018, Zi Lu, 23)

One of the most important instruments of Confucian sages with regard to achieving personal and social harmony was ritual music. It helped to expand the field of harmony from individuals and their interrelations to cosmic dimensions. Music thus helped in legitimising the "harmonising" actions of rulers and other guiding social authorities as something intrinsically cosmic. As Erica F. Brindley stated in her book on music and politics of harmony in early China:

Music, as I have argued so far, emerged as a distinct aspect of ritual practice with a life and significance of its own. Fused with concepts of 
harmony and tightly bound to the operations of the cosmos, music stood out from other traditional, cultural, and man-made practices. It took on meaning as that which was "natural" or "intrinsic" to the subtlest aspects of the cosmos. It thereby became something that rulers or anyone who sought authority and a privileged status or power vis-à-vis the cosmos held close to their hearts. (Brindley 2012, 63)

In their article "The Confucian Value of Harmony and its Influence on Chinese Social Interaction,"Xiaohong Wei and Qingyuan Li point out four main characteristics of harmony for (most) Confucians (儒家, followers of $R u$ or Rujia $)^{1}$ :

Harmony is an ethical notion, which describes how human beings ought to act. It is the Way, the Confucian way of life.

Harmony is, by its very nature, relational. It presupposes the coexistence of multiple parties. Harmony is achieved by coordinating different parties to behave cooperatively, with benevolence, authoritative conduct (ren 仁), righteousness, morality ( $y i$ 義/义), and ritual propriety ( $l i$ 礼) being the main criteria of cooperation.

Confucian harmony is not mere agreement without difference. When harmony is achieved, the coexisting parties still differ from each other; while harmony does not preclude sameness, sameness itself is not harmony. ... Since harmony is not a state but, more importantly, a process, disharmony is necessarily present during the process of harmonisation.

In the Confucian view, parties conjoined in a harmonious relationship mutually enable and limit one another. Put differently, a harmonious relationship implies that parties mutually complement and support each other. (Wei and Li 2013, 62)

From the Confucian perspective, striving for harmony necessarily encompasses self-cultivation, i.e. moral transformation of the actor so that he may realise the Way (dao 道). By practicing the rituals and respecting mutual responsibilities required to sustain so-called "five relationships" (father-son, husband-wife, older brother-younger brother, ruler-subject and friend-friend), Confucians tried to bring harmony to family, communal, and political life. Those who managed to

1 Although $R u$ or Rujia, the tradition (or the family) of scholars is the more correct name for the intellectual and cultural tradition which has been following the seminal thought of Confucius (the Master Kong - Kong Fuzi), I will use the established Latinised terms "Confucian" and "Confucianism." 
fully master this practice served as role models for those around them. In Confucianism, to follow the Way means to follow one's human nature (xing 性) and demonstrate benevolence (reciprocity) (ren) to other people. The Analects expresses this sentiment as follows:

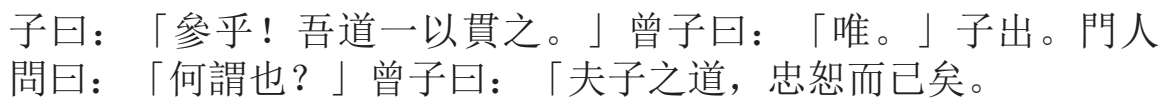

"Shen, a single thread runs through my dao." Master Zeng said, "Yes." The Master went out, and the other disciples asked, "What did he mean?" Master Zeng said, "The Master's dao is nothing other than loyalty and benevolence." (Eno 2015, 4, 15)

In ancient Confucian culture there are two main stages in the pursuit of self-cultivation: the “inner sage" (neisheng 內聖) and “outer kingliness" (waiwang 外王). The "inner sage" refers to the process of inner moral development, while the "outer kingliness" refers to the process of outward social development: here, one's social development is regarded as the elaboration of one's moral development. In another Confucian classic, The Great Learning (Daxue 大學), the two stages are described as follows:

物格而後知至，知至而後意誠，意誠而後心正，心正而後身修， 身修而後家齊，家齊而後國，國治而後天下平。自天子以至於庶 人，壹是皆以修身為本。其本亂而末治者否矣，其所厚者，而其 所薄者厚，未之有也！此謂知本，此謂知之至也。

Only after affairs have been aligned out may one's understanding be fully extended. Only after one's understanding is fully extended may one's intentions be perfectly genuine. Only after one's intentions are perfectly genuine may one's mind be balanced. Only after one's mind is balanced may one's person be refined. Only after one's person is refined may one's household be aligned. Only after one's household is aligned may one's state be ordered. Only after one's state is ordered may the world be set at peace. (ibid. 2016b, 1)

In the later developments of Confucianism, the idea of harmony took on different, sometimes contradictory interpretations. Xunzi understood harmony as the regulation of society and human behaviour that is in accord with established principles of behaviour ( $l i$ ) and regularity ( $y i$ 義) which follows the way of Heaven ( $t^{\prime} i e n$ 天). This regulation was strictly hierarchical and supported the central role of the "heavenly" Emperor in the Chinese state. As one of the main methods for the 
establishment and preservation of harmony, Xunzi suggested the establishment of different forms of punishment. (Rošker 2013,11) Xunzi was not alone with his idea of a hierarchically based harmony, as Mohists and Legalists argued for similar ideas.

Unlike Xunzi, Mengzi laid the greatest emphasis on cultivating the internal harmony between mean/balance (zhong 忠) and the inherently benevolent human nature (renxing 人性). Such harmony in one individual, when realised, spontaneously radiates outwards and helps in realisation of harmony in others. Mengzi discussed striving after harmony as the looking for spontaneous interpersonal coherence among people, and as the ability for conforming to the tradition the old Sages (ibid., 9-10).

It is rather clear that the concept of the hierarchically ordered social harmony was much more "useful" for the Chinese rulers than Mengzi's more ethically and personally coloured concept. This holds true particularly for the state-legitimised Confucianism, where the idea of harmony as an ideological cover for preserving peace and absolute imperial power prevailed in a socially strictly stratified Chinese society, while the idea of harmony as an ethical-personal guide found its embodiment in the circles of "literati" and autonomous thinkers. However, as open conflict between these two lines of thought and practices very seldom if at all appeared in China, the differences often remained covered with symbolic and metaphoric language. The picture of a series of heroic battles pitching ethically and spiritually harmonised individuals against an oppressive pseudo-harmonised social system in traditional China is thus completely inappropriate. In traditional China a self-cultivated individual without strong social support was soon pressed into social isolation and condemned to personal defeat. $^{2}$

The ideal and the practice of the strictly stratified harmonisation of society almost completely eliminated open social criticism.

In a society ruled by Emperors under a "mandate of heaven" and strictly organised according to rules of authority and obedience through a long list of dynasties, political critique incurred heavy punishment. ... Criticism in traditional China shows itself mainly in the arts, and the interpretation of classics. Political criticism is best to be avoided, unless official corruption severely threatens ordinary life. (Chu 2012, 53)

2 However, there were some cases of virtuous individuals who openly and clearly criticised the unjust and unwise measures of some Emperors and the state administration, e.g. some brave literati such as Fang Xiaoru in the 14th century, and Hai Rui and Zuo Guangdou in the 16th century, among others (Huang 1995, 138). 
I believe much the same holds true for the actual understanding and propagation of a "harmonious society" in China under Hu Jintao and Xi Jinping (although in this case the interpretation of the Chinese classics is replaced by the interpretation of Marxist and Maoist classics). Jana Rošker, in her analysis of the use of the concept of harmony in contemporary People's Republic of China, states that this understanding and propagation "derives directly from Xunzi's interpretation of this notion. They can thus be regarded as Confucian, but in terms of their fundamental aims they derive from elaborations of the original Confucian teachings which were functional to the integration of despotic elements into the new state doctrine formulated in the Han period.” (Rošker 2013, 11-2)

Many modern Chinese political and cultural theoreticians (both from the People's Republic and abroad) are highly sceptical of this new Xunzian reaffirmation of the concept of harmony in "late-communist" China. More specifically, I am inclined to think that it is impossible to find any sound Marxist interpretation of such a concept as pertaining to social harmony.

Marx rarely spoke of social harmony, and even then his remarks were mostly sceptical and/or negative. In his view, the term stands for a surface phenomenon, seemingly harmonious societal interrelationships covering up the brutal reality of social and economic contradictions. For example, in Economic Manuscripts (Grundrisse) Marx harshly criticises Fredric C. Bastiat in France and Henry C. Carey in the USA because of their advocacy of the thesis of the "harmony of interests" in capitalist society. Carey argued for a harmonious relationship between wages and labour productivity, so that the former rise in proportion with the latter, while Bastiat defended the idea of bourgeois society based on harmonious laws. In Marx's words:

Both therefore find it necessary to criticise the theoretical expression which bourgeois society has historically achieved in modern political economy as a misunderstanding and to demonstrate the harmony of the relations of production at the point where the classical economists naively analysed their antagonism. The entirely different, even contradictory national context, from which their writings derive, nevertheless impels them in the same direction. (Marx 2010c, 6)

Marx was especially critical of the idea of harmonious class relations. Graeme Duncan in his book on Marx and Mill writes:

In Marx's view classes as such had to be destroyed, He felt that it was futile to seek long-term harmonious relations between entities which 
were by nature antagonistic, and bitterly attacked talk of the political, economic and social equalisation of classes. The "equalisation of classes," literary interpreted, is nothing but another way of saying the "harmony of capital and labour" preached by the bourgeois Socialists... For Marx, the harmonisation of classes was, like the goal of private property for all, an impossible aspiration, and one quite inadequate to realise human emancipation. (Duncan 1973, 188-89)

Marx would probably be very critical of, if not downright horrified at, the idea of building a harmonious socialist society before the abolition of private property, the money economy and the circulation of capital. He would also sharply oppose the Confucian and Neo-Confucian notions of state-regulated harmony, decrying them as state-ideological means intended to create the impression of "social balance" and cover up various forms of social oppression present in the old and modern Chinese states.

Mao Zedong, the leader of socialist revolution in China, also very rarely spoke on social harmony as an aim of the movement. Sometimes he spoke about "entering into the Great Harmony" which will appear after abolishing the class society in China, but noted that before this a strict "people's democratic dictatorship" under the leadership of the Communist Party would be necessary (Mao Tse-Tung 1961, 412, 413, 418).

However, in spite of Marx's criticism of the idea of a harmonious economy or harmonious society, positive allusions to the concept of such a society can be found, particularly in Marx's early descriptions of the higher forms of communism, e. g. in the Economic and Philosophic Manuscripts (from 1844):

Communism as the positive transcendence of private property human self-estrangement, and therefore as the real appropriation of the human essence by and for man; communism therefore as the complete return of man to himself as a social (i.e., human) being-a return accomplished consciously and embracing the entire wealth of previous development. This communism, as fully developed naturalism, equals humanism, and as fully developed humanism equals naturalism; it is the genuine resolution of the conflict between man and nature and between man and man-the true resolution of the strife between existence and essence, between objectification and self-confirmation, between freedom and necessity, between the individual and the species. Communism is the riddle of history solved, and it knows itself to be this solution. (Marx 2010a, 296-97) 
This is a powerful visionary and utopian picture of humanity, nature, and society. It could thus be argued that, for Marx, the notion of harmonious relationships between human beings and nature, and with each other, was conceived as a utopian idea, but it also contains the necessary critical standpoint to all attempts at realising social harmony in a class society.

Marx believed that the development of modern productive forces, especially scientific production, would sooner or later enable us to enter into a class-less society, "and that, like slave labour, like serf labour, hired labour is but a transitory and inferior form, destined to disappear before associated labour plying its toil with a willing hand, a ready mind, and a joyous heart" (Marx 2010b, 11). Marx also hoped that the first worker co-operatives, which appeared in England and the USA in the middle of 19 th century, represented the rudimentary elements of a new society.

Duncan contrasted Marx's concept of a harmonious class-less society with Mill's and other liberals' concepts of a modern society which do not try to eliminate private property or promote social hierarchy as a reasonable social goal. Duncan warned of the danger "that the removal of all the limiting institutions of liberal capitalist society, which both constrain and define men, would lead, not to the emergence of the free and co-operative individual, but to an even more restrictive and destructive social order." (Duncan 1973,184) We are all familiar with the bad results brought forth by the "socialist experiments" which took place in the former Soviet Union and other "Eastern" countries, as well as with the serious problems with even elementary human rights and freedoms in modern, socialist China.

In spite of Marx's criticism of the grand-scale ideal of social harmony, the proposal for achieving some "local" and "partial" realisation of harmony in an actual social setting are much more feasible. Confucian, and especially Mencian, concepts of harmony seem especially relevant, in that they favour realisations of harmony in the everyday lives of men. Such concepts and ideals of harmony try to balance the ethical and spiritual development of individuals and the community without the need for any compulsory social hierarchy and political oppression. I believe that such concepts of harmony may be used in the development of some alternative concepts which do not present an ideological covering of the class division and brutal reality of various social and economic contradictions. They may thus be highly relevant for the democratic and genuinely emancipatory development of China and modern world in general.

Marx's criticism of the concept of social harmony as pertaining to actual capitalist societies is still more than relevant if one considers the disturbing social conditions in modern industrial societies burdened with ever greater social and economic inequalities, growing destruction of the social state and natural world, and with the growing threat of global economic and ecologic catastrophes. 
Marx's criticism reminds us also of the need for much stronger and active forms of human interconnectedness than those encompassed in the ideal of social harmony. Marx gives us many hints as to how this interconnectedness should be manifested, e.g. by his demand for collective solidarity of workers in their resistance to capitalist living conditions.

For Marx, workers need different forms of collective solidarity so as to become the social subject which can become a truly revolutionary force. It is through political practices of engaging in joint struggle that workers, who share objective economic interests (a "class in itself"), become aware of their shared class interests and develop relationships of class solidarity (a "class for itself").

In his book Global Solidarity, Laurence Wilde writes that the quest for solidarity originated in the nineteenth-century struggles of working-class social movements for democratic rights and economic security (Wilde 2013, 258). From the very outset it was inspired by an internationalist vision, but that was soon eclipsed by the rise of popular nationalism. Wilde stresses that

now, in the era of globalisation, a global political agenda has emerged at a time when many of the old social movements have suffered dispiriting setbacks. At the same time, new movements have developed to revive the hope that solidarity, a feeling of sympathy shared by subjects within and between groups, impelling supportive action and pursuing social inclusion, may yet be realised. (ibid.)

The modern world does not know of classical class antagonisms, e.g. the conflict between the capitalist and worker class, but it knows of a meshwork of deep social injustices and social conflicts which are locally and globally interconnected and produce the large-scale experience of growing inhumanity. Wilde pleads for a global network of active solidarity movements which perhaps come to a collective consciousness of their common interests. In these conditions new forms of solidarity may appear which grow out of our basic mutual esteem for each other and not out of some specific interests.

This idea expresses the strong need for new, trans-political forms of communality, basic democracy, and global social movements which may bring relevant alternatives to the dominant late-capitalist modes of production and social relationships. Not by striving for global revolutions, but by revitalisation of the common and simultaneous defence of the freedom and human rights of all people and virtuous humaneness. It is here that new occasions open up for a historically relevant Sino-Western "synchronisation," namely in the need for a novel and broader understanding of the interrelation between the defence of dignity of individuals and 
the cultivation of personal dignity, benevolence and humaneness of "worthy" individuals. It is quite clear that the West was mainly preoccupied with the defence of the personal and civil dignity of individuals, which includes striving for freedom and defending the human rights of ever more people, while China was focusing primarily on the cultivation of personal dignity and ethically worthy individuals. Western philosophers and social theoreticians dealt mainly with the defence of human dignity of men in general, especially in terms of the political freedoms and the fundamental rights of individuals, but they invested significantly less effort in recognising and realising the ethical virtues which are necessary for a self-conscious and responsible human life. On the other side, Chinese philosophers and social theoreticians engaged mainly in a balance between the search for social harmony and moral self-cultivation, but they invested much less effort in the defence of broader social aspects of human dignity, especially in political freedoms and fundamental human rights.

It is true that Chinese cultural tradition included seeking some broader forms communality outside one's their family- and clan-solidarity, e.g. cultivation of true friendship (Vervoorn 2004), but this cultivation was mostly limited to circles of "true gentlemen" and rarely, except, say, in Mohist ideas of inclusive concern and care for all, became the cultivation of commonality with the people, oppressed or painfully subordinate men and women. Sure, there were some important exceptions to this general trend, e.g. Confucius had some students from poor families, some notable Confucians showed sincere concern for the poor and abused common people, and Zhuangzi in some of his stories explicitly empowered women, elderly and disabled persons and so on, but these cases of the cultivation of trans-personal and truly social solidarity as a rule lacked justified forms of collective action on a properly political level, and thus did not change the general trend of mostly personal ethical cultivation. Here lie the inherent social and historical limits of the classical Chinese concepts and ideals of social harmony. These concepts and ideals do not suffice for the development of new, trans-political forms of communality. ${ }^{3}$

3 In spite of the limits for the development of some broader, transpersonal forms of communality in traditional China, Confucians knew the broader, utopian concept of communality, namely the ideal picture of Great Unity (datong) where the world is shared by all men alike, men regard all parents as their own parents, and all sons as their own sons, they use their power for the best of all men, where no thieves and rebels exist, etc. This ideal was first presented at the beginning of classic book Liji (Book of Rites). In this text Confucius presented this ideal as the portrait of the long lost Golden Age, and implicitly as a hope for at least partial realisation in the future. The concept of datong came again to the fore of Chinese political and social thought in the 19th and 20th centuries as Chinese thinkers confronted the challenges of the West and modernisation, most notably in the reformist and utopian writings of Kang Yuwei (1858-1927) (Chen 2011). 
Similarly, in the West one can find some cases of clear efforts in the cultivation of ethical virtues and the development of self-conscious and responsible individuals, e.g. some Christian saints, early scientists and spiritually awaked persons, but there was no elaborated common culture and practice comparable with the ever growing cultivation of civic virtues and the struggles to establish basic human rights for all.

What we need now, in the conditions of late modernity, is some synthesis of "Western" and "Eastern" (e. g. Chinese) ways of individual and social cultivation which contains a reciprocal and universal cultivation that may give reasons for active broader solidarity with oppressed, excluded, and persecuted people. Without this type of cultivation, any realisation of post-traditional solidarity and community would quickly dissipate into a meshwork of superficial emotions of triviality and political romanticism. The same holds true for any contemporary attempts at manifesting harmony, be it in an individual, among individuals, or in a society. Manifesting harmony can become something worthwhile only if it becomes a part of a broader project, namely that of active solidarity based on the reciprocal and universal cultivation of personal dignity and virtuous humaneness.

Certainly, we have to take care not to fall in the trap of adopting some easy shortcuts in the construction of such synthesis, e.g. by adding some Eastern practices of "spiritual" embodiment (like those of Indian or Chinese yoga, meditation, Tai Chi, and so on) to social and political activism, or by adding some Western practices of party-activism, public discussions and civil society movements to the Eastern practices of personal and inter-personal harmonisation. Such short-cuts would inevitable produce deeply illusory feelings of self-righteousness, frustrations because of social and political inefficiency, and instrumentalisation of individual efforts for some other, non-emancipatory interests, e.g. those of Capital, populist politicians, and fundamentalist movements.

What we really need is to achieve a cultural and social context which would foster a stronger connection between the "inner" personal-ethical attitude of individuals and their "outer" emancipatory socio-political activity. I believe that the common work of many people in the world for global solidarity, as expressed by Laurence Wilde, may present such a context.

In his book Disrespect Axel Honneth, a student of Jürgen Habermas, put forward a similar idea when he wrote of the need for a deeper mutual esteem among men and their active bearing of responsibility for others:

in this sense, mutual esteem consists in our viewing each other in the light of values that cause the capacities and characteristics of other persons to 
significant for our common activity. Relationships of this kind are to be considered instances of solidarity because they elicit not mere passive tolerance with respect to other persons, but emotional participation in their individual particularity. It is only to the degree to which I actively bear responsibility for another person's ability to develop qualities that are not my own that our shared goals can be realised. (Honneth 2007, 261)

A central claim of Honneth's theory is that there is a strong moral force inherent in the expectation of recognition involved in struggling for rights and forging solidarity. Honneth supposes there are moral feelings of indignation against various forms of disrespect that act as an important motivating force for the members of any organised struggle. Honneth further believes that new forms of communities, the "post-traditional communities" which are based on the given kind of solidarity, may appear which transcend the traditional political communities and institutions of liberal democracy.

I believe that this type of solidarity based on the cultivation of mutual esteem among individuals, and emotional participation in their individual particularities, necessarily guides us in the transition from the level of interpersonal solidarity to the global network of post-traditional communities and solidarity. This process transcends the realm of politics as striving to dominance over people and nature. It presents the basic socio-historical context and cultural support for new, deeper forms of personal, inter-personal and trans-personal harmony.

\section{References}

Brindley, Erica, F. 2012. Music, Cosmology, and the Politics of Harmony in Early China. Albany: State Universe of New York Press.

Chen, Ahu. 2011. "The Concept of "Datong" in Chinese Philosophy as an Expression of the Idea of the Common Good." The HKU Scholar Hub, The University of Hong Kong. Accessed April 19, 2018. https://hub.hku.hk/bitstream/10722/143448/2/Content.pdf?accept $=1$.

Chu, Yingchi. 2012. "Why Does China Fear Critical Discourse? In Civilisation and Fear: Anxiety and Writings of the Subject, edited by W. Kalaga and A. Kliś, 47-60. Cambridge: Cambridge Scholars Publishing.

Eno, Robert, trans. 2015. The Analects of Confucius. An Online Teaching Translation. Bloomington: Indiana University. http://www.indiana.edu/ p374/Analects_ of_Confucius_(Eno-2015).pdf.

- trans. 2016a. "The Doctrine of the Mean." In The Great Learning and The Doctrine of the Mean: Translation, Notes, and Commentary, 33-55. http://www. indiana.edu/ p374/Daxue-Zhongyong_(Eno-2016).pdf. 
—, trans. 2016b. "The Great Learning." In The Great Learning and The Doctrine of the Mean: Translation, Notes, and Commentary, 11-24. Bloomington: Indiana University. http://www.indiana.edu/ p374/Daxue-Zhongyong_(Eno-2016).pdf.

Duncan, Graeme. 1977. Marx and Mill. Two Views of Social Conflict and Social Harmony. Cambridge: Cambridge University Press.

Honneth, Axel. 2007. "Posttraditional Communities: A Conceptual Proposal." In Disrespect: The Normative Foundations of Critical Theory, edited by A. Honneth, 254-61. Cambridge: Polity Press.

Huang, Martin, W. 1996. Literati and Self-Re/Presentation. Stanford: Stanford University Press.

Lee, Yueh-Thing, Yang Honggang, and Wang Min. 2009. "Daoist Harmony as a Chinese Philosophy and Psychology." Peace and Conflict Studies 16 (1): 68-81. http://nsuworks.nova.edu/cgi/viewcontent.cgi?article=1103\&context=pcs.

Lunyu 論語 s.d. (The Analects). In: Chinese Text Project. Pre-Qin and Han. Accessed May 10, 2018. https://ctext.org/analects.

Mao Ze-Dong. 1961 “On the People's Democratic Dictatorship." In Selected Works of Mao Tse-Tung, vol. 4, 411-24. Oxford and New York: Pergamon Press.

Marx, Karl. 2010a. "Economic and Philosophic Manuscripts of 1844." In Collected Works, vol. 3, by Karl Marx and Friedrich Engels, 229-348. London: Lawrence $\&$ Wishart.

—. 2010b "Inaugural Address of the Working Men's International Association." In Collected Works, vol. 20, by Karl Marx and Friedrich Engels, 5-13. London: Lawrence \& Wishart.

—. 2010c. "Economic Manuscripts of 1857-58." In Collected Works, vol. 28, by Karl Marx and Friedrich Engels. London: Lawrence \& Wishart.

Mengzi. 2018. The Works of Mencius. Chinese Text Project. Harvard. https://ctext. org/mengzi.

Rošker, Jana. 2013. "The Concept of Harmony in Contemporary P. R. China and in Taiwanese Modern Confucianism." Asian Studies 1 (15, 2): 3-20.

Vervoorn, Aat. 2004. "Friendship in Ancient China." East Asian History, 27-32.

Wang, Zhihe. 2012. Process and Pluralism: Chinese Thought on the Harmony of Diversity. Frankfurt/M: Ontos.

Wei, Xiaohong, and Li Qingyuan. 2013. "The Confucian Value of Harmony and its Influence on Chinese Social Interaction." Cross-Cultural Communication 9 (1): 60-66.

Wilde, Laurence. 2013. Global Solidarity. Edinburgh: University Press. 